\title{
Elevated levels of microbial activity in the coral surface microlayer
}

\author{
John H. Paul, Mary F. DeFlaun \& Wade H. Jeffrey \\ Department of Marine Science, University of South Florida, 1407 th Avenue South, St. Petersburg, Florida 33701, USA
}

\begin{abstract}
Microbial biomass and activity parameters were measured in the mucus-rich, coral surface microlayer (CSM) and in the waters overlying coral reefs in the Dry Tortugas and Key West Florida, USA. For all parameters measured (thymidine incorporation, bacterial direct counts, primary production, chlorophyll a, dissolved DNA, and particulate DNA), the CSM values were significantly greater than the overlying water values on a per volume basis. Enrichment in the CSM ranged from nearly equal to 7.5 -fold for bacterial direct counts to 18 to 280 -fold for chlorophyll a. Microautotrophic processes in the CSM were due almost exclusively to the activities of free-living zooxanthellae, while activities in overlying waters were dominated by autotrophic picoplankton. Higher cellular rates of thymidine incorporation (1.23 to 50 times greater) indicated that bacteria in the CSM were growing faster than those in the water column. Bacterial production estimates on a per area basis in the CSM (thickness $\simeq$ several $\mathrm{mm}$ ) were equivalent to that of the whole water column over the reef (depth 1 to $4 \mathrm{~m}$ ). Size fractionation of the CSM indicated that most of this bacterial activity was associated with particles $>1 \mu \mathrm{m}$, while overlying waters were dominated by $<1 \mu \mathrm{m}$, free-living bacterioplankton. No significant temporal or spatial variation was noted in these parameters in the overlying waters in a transect across the reef or in a diel study. However, all values in the CSM (except direct counts) were significantly greater at a midnight sampling than at a noon sampling. Dissolved deoxyribonuclease activity was found in both environments. Collectively these results indicate that the CSM contains an extremely active microbial community, comparable to that found in a eutrophic estuary. These results are discussed in terms of reef production in oligotrophic environments and nutrient dynamics.
\end{abstract}

\section{INTRODUCTION}

Our understanding of the role of bacteria in coral reef ecosystems is still evolving. Sorokin $(1971,1973)$ first pointed out the quantitative significance of bacterial processes by describing bacterial rates of 'destruction' of organic matter that exceeded primary production in the water column and sediments of coral reefs. Since corals fed upon bacteria, he postulated that the role of bacteria was to convert DOC into a form utilizable by corals (Sorokin 1973). Although criticized from a methodological standpoint, much of Sorokin's work forms the framework of recent investigations into coral reef microbial ecology.

Improved methods for estimating microbial population size (Hobbie et al. 1977, Paul 1982, Moriarty 1983) and growth rate (Karl 1979, Fuhrman \& Azam 1980, 1982, Karl \& Bossard 1985) have been employed to explore the role of bacteria in coral reef ecosystems. The majority of these studies have been directed at measuring bacterial production in the water column
(Moriarty et al. 1985a) or the sediments (Burns et al. 1984, Moriarty et al. 1985b; for an excellent review see Ducklow in press).

Few studies have investigated the activity of microorganisms in the coral surface microlayer (CSM), the mucus-rich zone that extends a few $\mathrm{mm}$ from the coral surface (also termed the 'unstirred layer' by Segel \& Ducklow 1982). This environment has been shown to be richly colonized with bacteria (Disalvo 1971. Sieburth 1975), which are believed to grow at the expense of coral mucus (Rublee et al. 1980, Herndl \& Velimirov 1986)

Ducklow \& Mitchel (1979a, b) studied coral mucus composition in detail, and isolated mucus-degrading bacteria. These workers elucidated the relation between the stress response of corals and bacterial growth, which formed the groundwork of a model for bacterial production responding to coral stress (Segel \& Ducklow 1982).

The purpose of the present study was to compare the relative activities of the microbial populations of the 
CSM and the overlying waters. A second goal of the study was to extend our investigations of dissolved DNA in seawater to the reef environment. In this report we demonstrate a dramatic enrichment of microbial (both microautotrophic and microheterotrophic) activity in the CSM compared to the overlying water, a diel periodicity of this activity, and speculate on the importance of bacterial production in the CSM to reef ecology.

\section{MATERIALS AND METHODS}

Study site. The study was performed primarily at the patch reefs surrounding the Dry Tortugas (Fig. 1) during 2 cruises in June and August 1985. A sample was also taken over the reef at Sand Key, which is located $\sim 10 \mathrm{~km}$ southwest of Key West.

A complete description of the Tortugas reef environment appears in Halley (1979). Stns 8a, b, e to h were located over Montastrea annularis heads on the west side of Loggerhead Key at a depth of 1 to $2 \mathrm{~m}$. Stns 8c, d were in the spur and groove formation at the south end of Loggerhead Key in a depth of 3 to $5 \mathrm{~m}$. Stns IVa to e represented a transect across an Acropora cervicornis patch reef (Fig. 1 \& 2); Stn IVa was located over a seagrass bed (depth 10 to $12 \mathrm{~m}$ ); Stns IVb, c in the center of the A. cervicornis reef (depth 1 to $2 \mathrm{~m}$ ), Stn IVd over a dead $A$. cervicornis reef, and Stn IVe was over sandy bottom (depth 10 to $15 \mathrm{~m}$ ). A diel study was performed in the water over Stn IVc. The purpose of this study was to see if the reef released anything that might stimulate microbial biomass or activity of the water directly overlying the reef. Therefore, no attempt was made to track any particular water parcel. Stns $9 a_{\text {, }}$ $b$ were located over a small patch reef of $M$. annularis near Garden Key. Sand Key samples (Stns 10a, b) were taken over an Acropora palmata reef in $<1 \mathrm{~m}$ water.

Water overlying the reef (usually $<1 \mathrm{~m}$ from the coral surface) was sampled with 81 Niskin bottles by scuba or skin divers. The CSM was sampled with sterile or ethanol-rinsed $50 \mathrm{ml}$ plastic syringes (no needle) by scuba or skin divers. Care was taken not to collect coral tissue or damage the coral surface by accidental abrasion in wave surge.

Processing of water samples was initiated usually within $20 \mathrm{~min}$ but in no case over $1 \mathrm{~h}$ of collecting. All filtrations were performed at $\leq 130 \mathrm{~mm} \mathrm{Hg}$ vacuum to minimize cell lysis. An equal volume of the sample was prefiltered through a $1 \mu \mathrm{m}$ pore-size Nuclepore filter to provide the bacterial-enriched $<1 \mu \mathrm{m}$ fraction. Samples for chlorophyll a, particulate DNA, and bacterial direct counts were processed as described previously (Paul \& Carlson 1984, Paul et al. 1985). Dissolved DNA samples were filtered through a $0.2 \mu \mathrm{m}$ Nuclepore filter and ethanol precipitated as described by Deflaun et al. (in press). The rate of ${ }^{3} \mathrm{H}$-thymidine incorporation into cold trichloroacetic acid (TCA) insoluble material was measured by a slight modification of the Fuhrman \& Azam (1982) method. ${ }^{3} \mathrm{H}$ [methyl]-thymidine $\left(69 \mathrm{Ci} \mathrm{mmol}^{-1}\right.$; ICN Radiochemicals) was added to a water sample for a final concentration of $7.25 \mathrm{nM}$. Samples were filtered immediately $(\mathrm{T}=0)$, at 30 , and at $60 \mathrm{~min}$ on $25 \mathrm{~mm}, 0.2 \mu \mathrm{m}$ Nuclepore filters. Filters were washed $5 \times$ with $2.0 \mathrm{ml}$ cold $5 \%$ TCA. At Stns $8 \mathrm{c}$ and $d$, incorporation of thymidine into the protein fraction was measured as hot-TCA

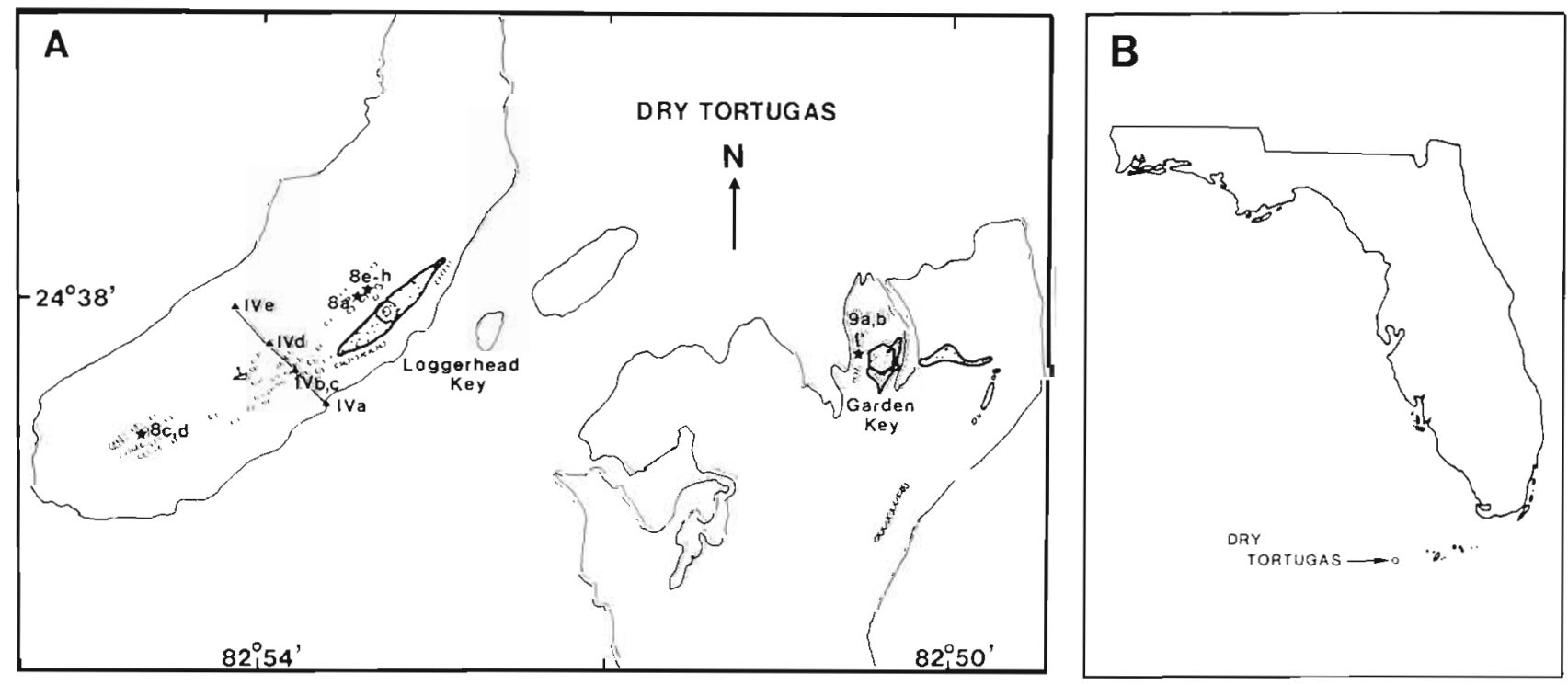

Fig. 1 (A) Sampling sites in and (B) location of the Dry Tortugas, Florida, USA. (A) Thin line: $30 \mathrm{ft}$ (9.14 m) isobath; stipple areas: land; curved marks: reef areas 
insoluble material (Fuhrman \& Azam 1982). Macromolecular precipitates on filters were prepared for liquid scintillation counting by the method of Kobayashi \& Harris (1978), and radioactivity determined in a TM-Analytic Delta 300 liquid scintillation counter.

Primary productivity in water samples was estimated by the ${ }^{14} \mathrm{C}$-technique with improvements as described by Carpenter \& Lively (1980). Water samples were amended with $\mathrm{NaH}^{14} \mathrm{CO}_{3}$ (Amersham; $54 \mathrm{Ci} \mathrm{mmol}^{-1}$ ) for a final radioactivity of $0.5 \mu \mathrm{Ci} \mathrm{m} l^{-1}$ in acid-cleaned, autoclaved polycarbonate flasks. Incubations were performed on deck in a water bath at ambient temperatures $\left(30\right.$ to $32^{\circ} \mathrm{C}$ ) under 2 layers of nitex neutral density screening ( $\sim 33 \%$ incident light intensity). Incubations were sampled at $\mathrm{T}=0,1$, and $2 \mathrm{~h}$.

To detect dissolved deoxyribonuclease activity, 13 $\mathrm{ml}$ of $0.2 \mu \mathrm{m}$ filtered sterilized water was incubated with ${ }^{3} \mathrm{H}$-[methyl-thymidine]-DNA made by nick translation of Escherichia coli chromosomal DNA template (Maniatis et al. 1982) for a final concentration of $34 \mathrm{ng}$ $\mathrm{ml}^{-1}$ and radioactivity of $0.26 \mu \mathrm{Ci} \mathrm{m} l^{-1}$. Two $\mathrm{ml} \mathrm{sam-}$ ples were taken as a function of time, and added to 0.4 $\mathrm{ml}$ of $0.1 \mathrm{mg} \mathrm{ml}^{-1}$ DNA followed by $2.5 \mathrm{ml} 10 \%$ cold TCA. After $2 \mathrm{~h}$, the precipitated DNA was collected by filtration on $0.2 \mu \mathrm{m}$ Nuclepore filters, and the filters washed with $2 \times 1.0 \mathrm{ml} 10 \%$ TCA. The filters and $1 \mathrm{ml}$ of the filtrates were counted for radioactivity by liquid scintillation counting.

\section{RESULTS}

The results of the transect across the Acropora cervicornis patch reef appear in Fig. 2. Particulate DNA, primary production, chlorophyll $a$, and bacterial direct counts showed little variation with respect to location in this transect. A slight but not significant variation was noted in dissolved DNA concentrations. Thymidine incorporation data was not available for this transect. Stns IVb and c were taken at the same location except that IVC represented a CSM sample. For all parameters measured, the CSM values exceeded the overlying water values by several fold, except for bacterial direct counts, which were not significantly different from the overlying waters.

Tables 1, 2 and 3 summarize comparisons between microbial parameters in overlying waters and in the CSM for the August cruise to the Dry Tortugas and Key West (Sand Key). Rates of primary productivity for the CSM exceeded the overlying waters by 5 to 140 -fold. Similarly, chlorophyll a values in the CSM exceeded the overlying waters 18 to 280 -fold. Microscopic examination of the CSM indicated that the chlorophyll $a$ and presumably the primary production in the CSM was due almost exclusively to zooxanthellae (Fig. 3). No other autofluorescing cell types were observed.

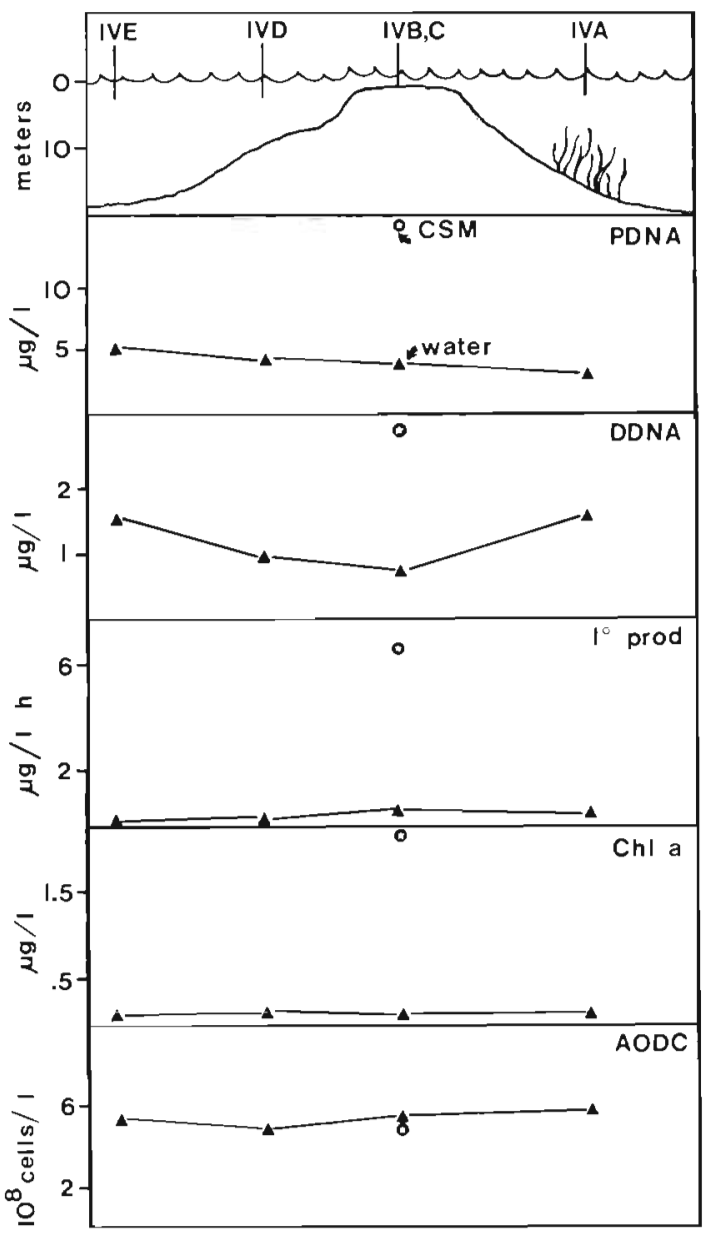

Fig. 2. Microbial parameters in the water and CSM in a transect over an Acropora cervicornis patch reef. Parameters measured were particulate DNA (PDNA), dissolved DNA (DDNA), primary productivity $\left(1^{\circ}\right.$ prod), chlorophyll a $(\mathrm{Chl} a)$, and bacterial direct counts (AODC)

The average specific rate of primary production $(\mu \mathrm{g}$ $\mathrm{C}[\mu \mathrm{g} \mathrm{Chl} \mathrm{a}]^{-1} \mathrm{~h}^{-1}$ was lower for the $\operatorname{CSM}(\overline{\mathrm{x}}=3.34 \pm$ 1.36) than the overlying water $(\overline{\mathrm{x}}=6.62 \pm 2.93$; $\mathrm{p}<0.05)$. This trend in decreased photosynthetic efficiency was not due to greater detrital chlorophyll content, since phaeopigment to chlorophyll a ratios were significantly lower in the CSM $(\bar{x}=0.144 \pm 0.064)$ compared to the overlying water $(\bar{x}=0.52 \pm 0.312$; $\mathrm{p}<0.05)$.

Table 2 summarizes microhetroterophic processes occurring in the CSM and overlying water. Molecular fractionation of TCA-precipitates indicated no incorporation of thymidine into protein in this environment. Bacterial activity as indicated by thymidine incorporation in the CSM exceeded that of the water column by 3.3 to nearly 90 -fold on a per volume basis. This large difference in bacterial activity was not reflected in cell densities, which ranged from nearly equal to 7.5 times greater in the CSM. Therefore, cellular rates of thy- 
Table 1. Microautotrophic processes in the CSM and overlying water. M: value obtained in CSM; B: value obtained in overlying water or bulk water; $M / B$ : ratio of these values

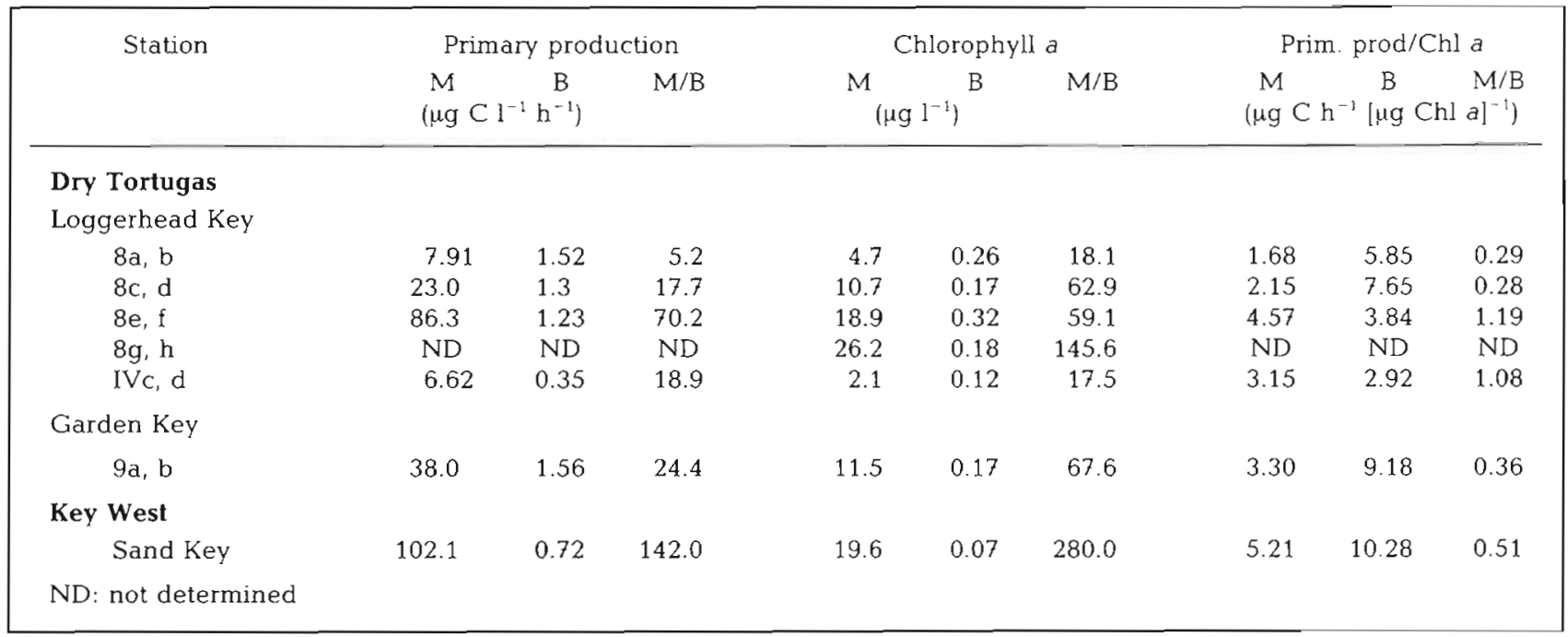

Table 2. Microheterotrophic processes in the CSM and overlying water. TI/DC: Thymidine incorporation per direct count or bacterial specific activity. $M, B$ : as in Table 1

\begin{tabular}{|c|c|c|c|c|c|c|c|c|c|}
\hline \multirow[t]{2}{*}{ Station } & \multicolumn{3}{|c|}{ Thymidine incorporation } & \multicolumn{3}{|c|}{ Direct counts } & \multicolumn{3}{|c|}{ TI/DC } \\
\hline & \multicolumn{3}{|c|}{$\underset{(p m o l ~}{M} \begin{array}{c}\text { B } \\
\left(h^{-1}\right)\end{array}$} & \multicolumn{3}{|c|}{$\left(10^{9} \mathrm{l}^{-1}\right)$} & \multicolumn{3}{|c|}{$\left(10^{-21} \mathrm{~mol} \mathrm{cell}{ }^{-1} \mathrm{~h}^{-1}\right)$} \\
\hline \multicolumn{10}{|l|}{ Dry Tortugas } \\
\hline \multicolumn{10}{|c|}{ Loggerhead Key } \\
\hline $8 a, b$ & ND & 0.97 & ND & 0.75 & ND & ND & ND & ND & ND \\
\hline $8 \mathrm{c}, \mathrm{d}$ & 5.98 & 0.67 & 89.3 & 1.14 & 0.63 & 1.81 & 52.5 & 1.06 & 49.5 \\
\hline $8 \mathrm{e}, \mathrm{f}$ & 21.3 & 2.32 & 9.18 & 1.94 & 0.26 & 7.46 & 11.0 & 8.92 & 1.23 \\
\hline $8 \mathrm{~g}, \mathrm{~h}$ & 67.9 & 1.63 & 41.7 & 1.49 & 0.43 & 3.47 & 45.6 & 3.79 & 12.0 \\
\hline IVc, d & 7.84 & 2.35 & 3.34 & 0.50 & 0.54 & 0.93 & 15.7 & 4.35 & 3.61 \\
\hline \multicolumn{10}{|l|}{ Garden Key } \\
\hline $9 a, b$ & 17.6 & 4.66 & 3.78 & 0.85 & 0.45 & 1.89 & 20.7 & 10.4 & 1.99 \\
\hline \multicolumn{10}{|l|}{ Key West } \\
\hline Sand Key & 229.0 & 3.36 & 68.2 & 0.88 & 0.17 & 5.18 & 260.2 & 19.8 & 13.1 \\
\hline ND: not determ & & & & & & & & & \\
\hline
\end{tabular}

midine incorporation were greater in the CSM, ranging from 1.23 to nearly 50 times that of the overlying water.

As part of our research on the dynamics of dissolved DNA in aquatic environments, we have measured DNA in both the CSM and overlying waters (Table 3 ). The CSM was found to be high in both particulate (or cell associated) and dissolved (extracellular) DNA. Enrichment in the CSM ranged from 3.77 to 36 -fold for particulate DNA, and from 1.8 to 11.7 -fold for dissolved DNA.

Values for the parameters measured from the reef environment are compared to those from oligotrophic oceanic and eutrophic estuarine environments in
Table 4. Values for the open ocean environment were measured on the same cruise at several stations in the Loop Current of the southeastern Gulf of Mexico, while the estuarine values are taken from a station in central Tampa Bay, Florida sampled monthly from February to May in 1985. Values for the open ocean and water overlying the reef are comparable, except that thymidine incorporation and chlorphyll a maxima were slightly higher for the latter environment. Coral surface microlayer values were comparable to those from a highly eutrophic environment. The DNA maximum in the CSM exceeded that from Tampa Bay, although we have measured particulate DNA in excess of $100 \mu \mathrm{gl}^{-1}$ in the Potamic River (Paul \& Myers 1982). Maximal 
Table 3. DNA in the CSM and overlying waters. M, B: as in Table 1

\begin{tabular}{|c|c|c|c|c|c|c|}
\hline & \multicolumn{3}{|c|}{ Particulate DNA } & \multicolumn{3}{|c|}{ Dissolved DNA } \\
\hline & M & $\left(\mu \mathrm{g} \mathrm{l}^{-1}\right) \quad \mathrm{B}$ & $\mathrm{M} / \mathrm{B}$ & M & $\left(\mu \mathrm{g} \mathrm{l}^{-1}\right) \quad \mathrm{B}$ & $\mathrm{M} / \mathrm{B}$ \\
\hline \multicolumn{7}{|l|}{ Dry Tortugas } \\
\hline \multicolumn{7}{|l|}{ Loggerhead Key } \\
\hline $8 a, b$ & 15.3 & 4.06 & 3.77 & 4.66 & 1.32 & 3.53 \\
\hline $8 \mathrm{c}, \mathrm{d}$ & 43.5 & 4.50 & 9.67 & 10.5 & 0.9 & 11.7 \\
\hline $8 e, f$ & 56.1 & 5.12 & 11.0 & 2.45 & 0.63 & 3.9 \\
\hline $8 \mathrm{~g}, \mathrm{~h}$ & 130.8 & 4.14 & 31.6 & 4.65 & 0.74 & 6.28 \\
\hline IVc, d & 14.7 & 3.73 & 3.94 & 2.91 & 0.72 & 4.04 \\
\hline \multicolumn{7}{|l|}{ Garden Key } \\
\hline $9 a, b$ & 26.6 & 4.22 & 6.30 & 7.43 & 1.17 & 4.34 \\
\hline \multicolumn{7}{|l|}{ Key West } \\
\hline Sand Key & 67.3 & 1.89 & 35.6 & 3.59 & 1.95 & 1.84 \\
\hline
\end{tabular}

Table 4. Comparison of the reef environment to offshore and estuarine environments. Open ocean: range of values for samples taken in Loop Current water of the southeastern Gulf of Mexico during the same cruise. Eutrophic estuary: range of values from central Tampa Bay for Feb to May 1985

\begin{tabular}{|c|c|c|c|c|}
\hline Parameter & Open ocean & Above reef & CSM & $\begin{array}{c}\text { Eutrophic estuary } \\
\text { (Tampa Bay) }\end{array}$ \\
\hline Particulate DNA ( $\left.\mu \mathrm{g} \mathrm{l}^{-1}\right)$ & $3.6-5.1$ & $2-5.2$ & $15.3-130.8$ & $23-33$ \\
\hline Dissolved DNA $\left(\mu \mathrm{g} \mathrm{l}^{-1}\right)$ & $0.7-4.1$ & $0.63-1.95$ & $2.45-10.5$ & $9-12.5$ \\
\hline Bacteria counts $\left(10^{9} \mathrm{l}^{-1}\right)$ & $0.35-0.9$ & $0.17-0.63$ & $0.75-1.94$ & $1.25-2.75$ \\
\hline Thymidine incorp. (pmol $\left.\mathrm{l}^{-1} \mathrm{~h}^{-1}\right)$ & $0.6-0.95$ & $0.67-4.66$ & $17.6-229.0$ & $26-120.3$ \\
\hline Thymidine inc./cell $\left(10^{-21} \mathrm{~mol} \mathrm{cell}^{-1} \mathrm{~h}^{-1}\right)$ & $1-6.1$ & $1.1-10.4$ & $11.0-260.2$ & $15-77.1$ \\
\hline Primary productivity $\left(\mu \mathrm{g} \mathrm{Cl}^{-1} \mathrm{~h}^{-1}\right)$ & $0.2-1.7$ & $0.72-1.56$ & $6.62-102.1$ & $73.5-466$ \\
\hline Chlorophyll a (ug $\left.l^{-1}\right)$ & $0.05-0.15$ & $0.07-0.32$ & $2.1-26.2$ & $7.0-54.0$ \\
\hline
\end{tabular}

thymidine incorporation values were greater from the CSM than the estuarine environment, yet primary productivity maxima were greater at the Tampa Bay station.

The results of size fractionation of samples from the reef environment appear in Fig. 4. The size distribution of the particulate parameters from the water overlying the reef was similar to that of an offshore environment in the preponderance of material in the $<1 \mu \mathrm{m}$ size fraction. Greater than $70 \%$ of the particulate DNA and bacterial direct counts were in the $<1 \mu \mathrm{m}$ fraction. Fifty to $100 \%$ of the thymidine incorporation was associated with particles $<1 \mu \mathrm{m}$ in size. Most of the chl a (50 to 72 $\%$ ) and a sizeable portion of the primary productivity (34 to $57 \%$ ) was $<1 \mu \mathrm{m}$, indicating the presence of autotrophic picoplankton. By contrast, the CSM particulate matter was considerably larger in size. Less than $10 \%$ of the primary productivity and $5 \%$ of the chlorophyll a were in the $<1 \mu \mathrm{m}$ size fraction. Although 58 to $93 \%$ of the bacterial direct counts were $<1 \mu \mathrm{m}$, only 19 to $39 \%$ of the thymidine incorporation was in this fraction. This indicates that the most active bacteria in the CSM were attached, filamentous, or simply large. The size distribution in the CSM resembles that found in the Alafia River in Tampa Bay (Fig. 4). Eukaryotic phytoplankton, filamentous bacteria, and attached bacteria are prevalent in this environment, as might be expected in a eutrophic environment.

During the June cruise, a diel study was performed at the site of Stn IVb, in the waters overlying the Acropora cervicornis patch reef (Fig. 5). Of all the parameters measured, only primary production showed a clear diel rhythm, probably due to the availability of daylight. A slight increase was noted in the $0400 \mathrm{~h}$ dissolved DNA value, but it is not known if this was a diel feature. The other parameters remained relatively constant. No CSM samples were taken during this diel study.

During the August cruise, the Montrastrea annularis heads west of Loggerhead Key were sampled at noon (Stns 8e, f) and midnight (Stns 8g, h). Values for the parameters in the CSM and overlying waters appear in Fig. 6. For every parameter measured except bacterial direct counts, the CSM midnight values exceeded the 

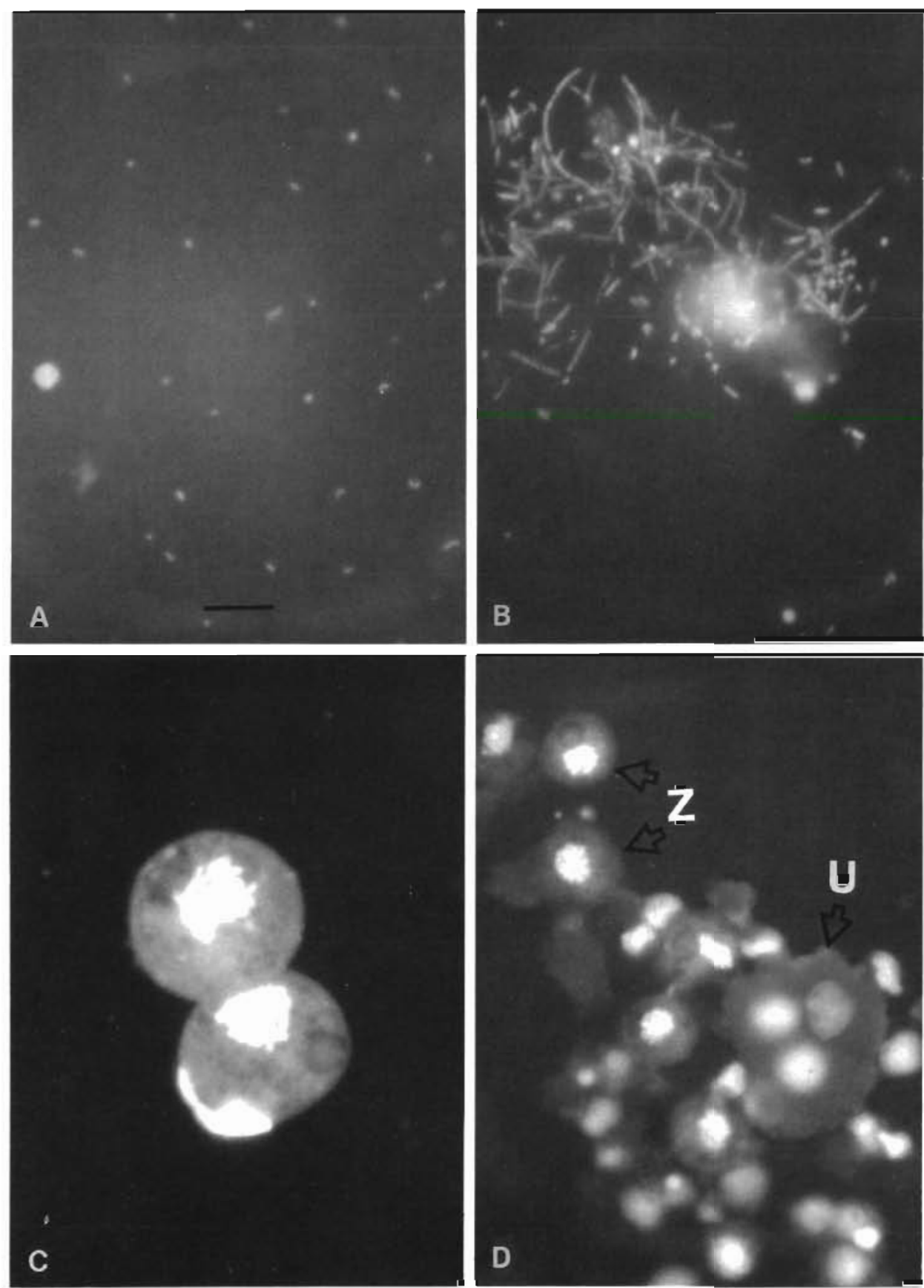

Fig. 3. Epifluorescence photomicroscopy of predominant cell types in the CSM and overlying waters. Water samples stained with $5 \times 10^{-6} \mathrm{M}$ Hoechst 33342. (A) Typical bacterial cells from waters overlying reef, Stn $8 \mathrm{~h}$. Bar $=5$ um; magnification is identical for b to d. (B) Bacterial cells from the coral surface microlayer, Stn 8a. Note preponderance of larger, chain-forming cells. (C) Zooxanthellae from the CSM, Stn $8 \mathrm{c}$. Bright spots in center of cells are chromosomes. (D) Cell types from the CSM midnight sampling, Stn 8g. Z: Zooxanthellae; U: unidentified amorphous cell type (see text for further details)

CSM noon values. More zooxanthellae were present in the midnight samples (Fig. 3). Additionally, nonphotosynthetic, amorphous cells were also present in the CSM at midnight (Fig. 3). These cells were thought to originate from the coral host, either as mucus cells (Walt Goldberg, Florida International University,
Miami, Florida, pers. comm.) or were macrophage-like cells (Dr. Robert Good, All Children's Hospital, St. Petersburg, Florida, pers. comm.). For the overlying water, there was no significant difference between the noon and midnight samples (Fig. 6).

Fig. 7 displays the results of extracellular deoxy- 

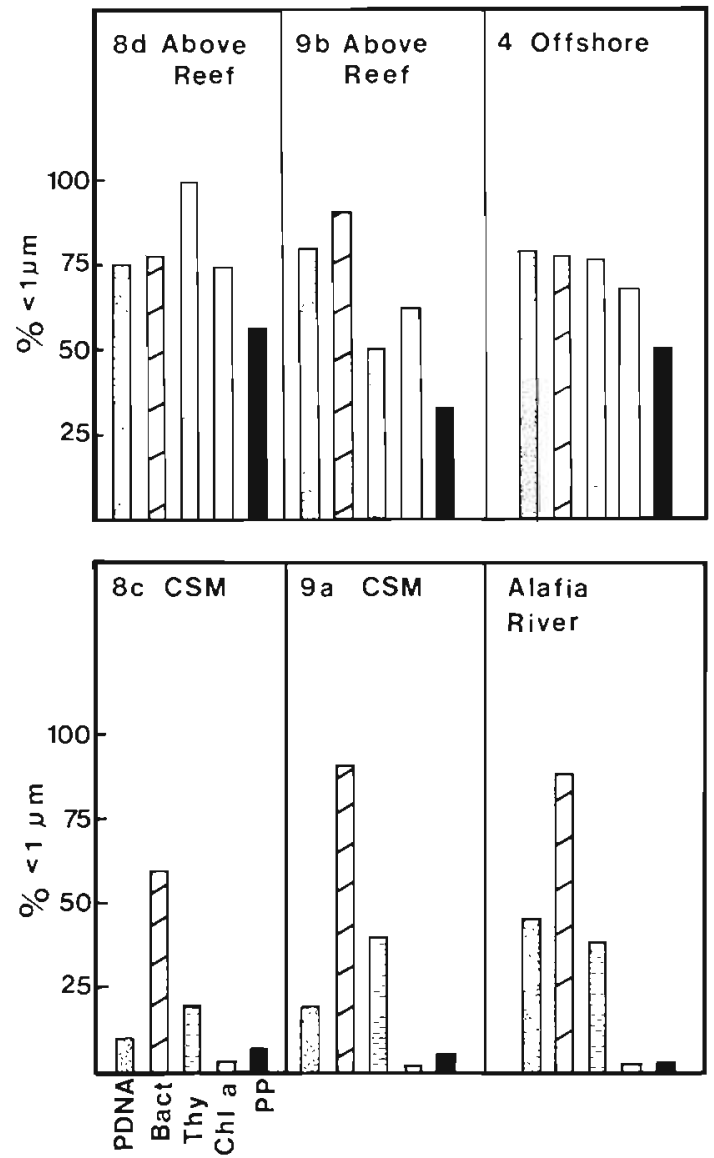

Fig. 4. Size distribution of particulate matter in water overlying reef (labelled 'above reef') and that of the CSM. Results are presented as $\%<1 \mu \mathrm{m}$ ', meaning in the 0.2 to $1.0 \mu \mathrm{m}$ fraction. Key for bars at lower left. 'PDNA' particulate DNA; 'Bact': bacterial direct counts; 'Thy': thymidine incorporation; 'Chl $a$ ': chlorophyll $a$; 'PP' primary productivity. For comparison, size distributions of the oligotrophic Gulf of Mexico ('offshore') and the eutrophic Alafia River of Tampa Bay ('Alafia River') are provided

ribonuclease assays. In both water column and CSM samples, exogenous ${ }^{3} \mathrm{H}$-DNA was hydrolyzed to acidsoluble material, as determined by the disappearance of TCA precipitable radioactivity and appearance of TCA soluble radioactivity. The results were not caused by tritium exchange with water as indicated by the boiled controls, which possessed no DNase activity.

\section{DISCUSSION}

Our results indicate that the coral surface microlayer contains a quite active bacterial and microalgal community. The nutritive potential of coral mucus has been known for some time (Johannes 1967, Benson \& Muscatine 1974, Ducklow \& Mitchell 1979a, b, Rublee et al. 1980, Herndl \& Velimirov 1986). Yet, to our

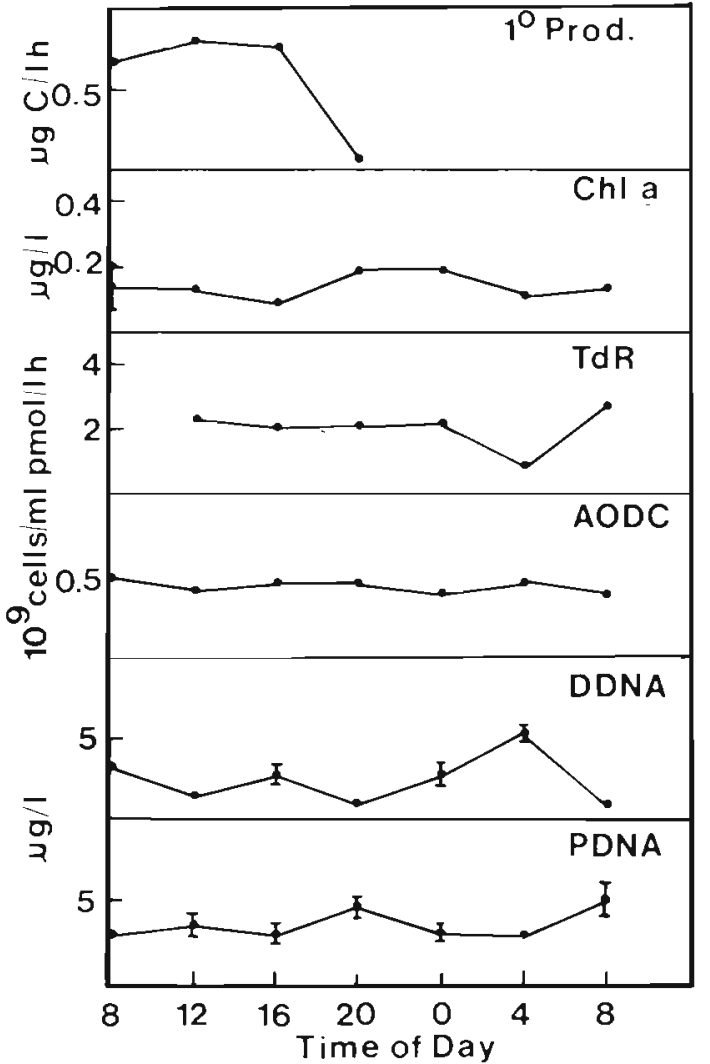

Fig. 5. Results of a diel study of microbial parameters in waters overlying the patch reef sampled in Fig. 2. Abbreviations of parameters measured as in Fig. 2., except that IdR is thymidine incorporation. Data was not available for TdR at the first 0800 sample, and $1^{\circ}$ productivity measurements were not performed after $2200 \mathrm{~h}$ of the first day. SD given where larger than symbol size

knowledge, measurements of the microbial activity in the mucus compared to the overlying water by direct techniques have not been reported.

Other investigators have found spatial and temporal variation in particulate organic matter, microbial biomass, and activity in the waters above reefs. Westrum \& Meyers (1978) found elevated POC levels over a reef crest, and Moriarty et al. (1985a) found high bacterial activity over a reef flat and a seagrass bed. Our transect showed little spatial variation in water column parameters where samples were located above a patch reef, seagrass bed, dead reef, or sandy bottom. The diel variation we noted in the CSM was not found in the overlying waters on 2 separate occasions. These findings also are in contrast to those of Moriarty et al. (1985a) for the overlying waters of a reef at Lizard Island. Moriarty found maximal thymidine incorporation values at $1600 \mathrm{~h}$ that exceeded the 900 and $1200 \mathrm{~h}$ sample by nearly 6 -fold. The differences noted between our study and his may be related to the differing reef environments. Lizard Island has an expansive reef 

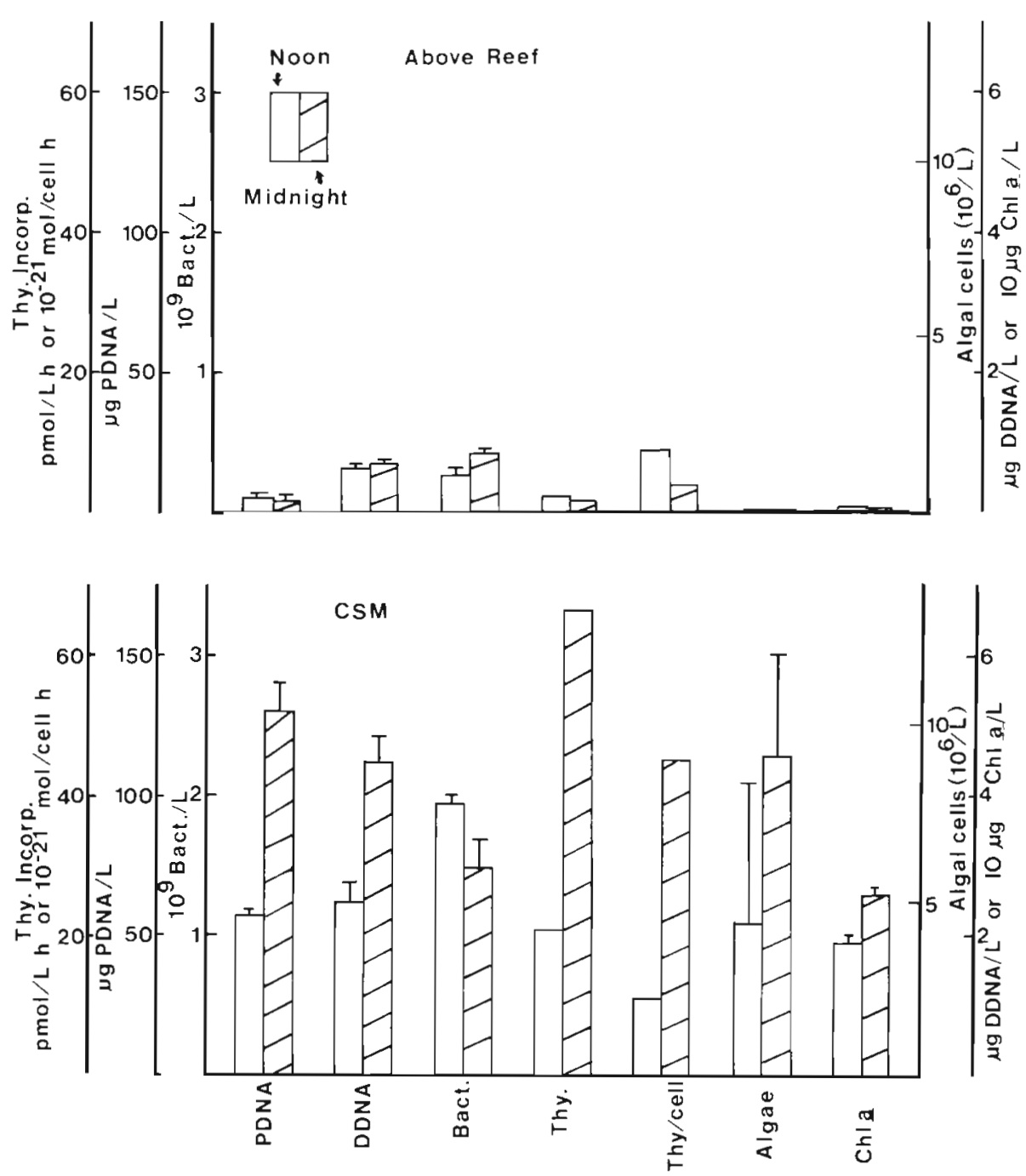

Fig. 6. Noon and midnight sampling of the overlying water and CSM of Stn 8 e to h. Parameters are those described in text. 'Algae': direct count of number of zooxanthellae in samples. Since no primary production measurements were made at midnight, no data is presented for this parameter

flat behind a reef crest, whereas the Tortugas is more dominated by isolated patch and fringing reefs. Our results imply, at least for the Tortugas, that the reef overlying waters are relatively homogeneous in terms of microbial parameters in space and time, not varying significantly from offshore Gulf Stream or Loop Current water. In contrast, the CSM is a dynamic environment, showing greater variability and productivity. Coral feeding behavior and polyp opening are known to occur more frequently at night. Perhaps this polyp activity allows for more mucus release and microbial growth.

It is interesting that the specific rates of primary productivity were lower in the mucus than the overlying waters. This implies that the zooxanthellae in the mucus are less efficient than the picoplankton in overlying waters. It may be that the zooxanthellae in the mucus are those ejected from the coral host and are less photosynthetically active (dormant and/or dying) than those in the coral tissue. However, the low phaeopigment to chlorophyll a ratios argue against the presence of dead or detrital algal cells in the CSM. It is more likely that incubation of the zooxanthellae without the coral host (and host metabolic products which form the source of algal nutrients) results in lower CSM primary production values than if incubations had occurred in situ on the coral surface.

The absolute value of primary production for both the water column and CSM may be viewed as conservative, since incubations were performed under 2 layers of nitex screening. This was our standard incubation method for all stations in this study and others (Paul unpubl.). We view our primary production values as an estimate of microalgal activity for comparative purposes between the CSM and other environments. Thus, the level of algal activity and biomass (per volume water) is comparable to that in a eutrophic estuary. Although nutrient concentrations in the CSM were 


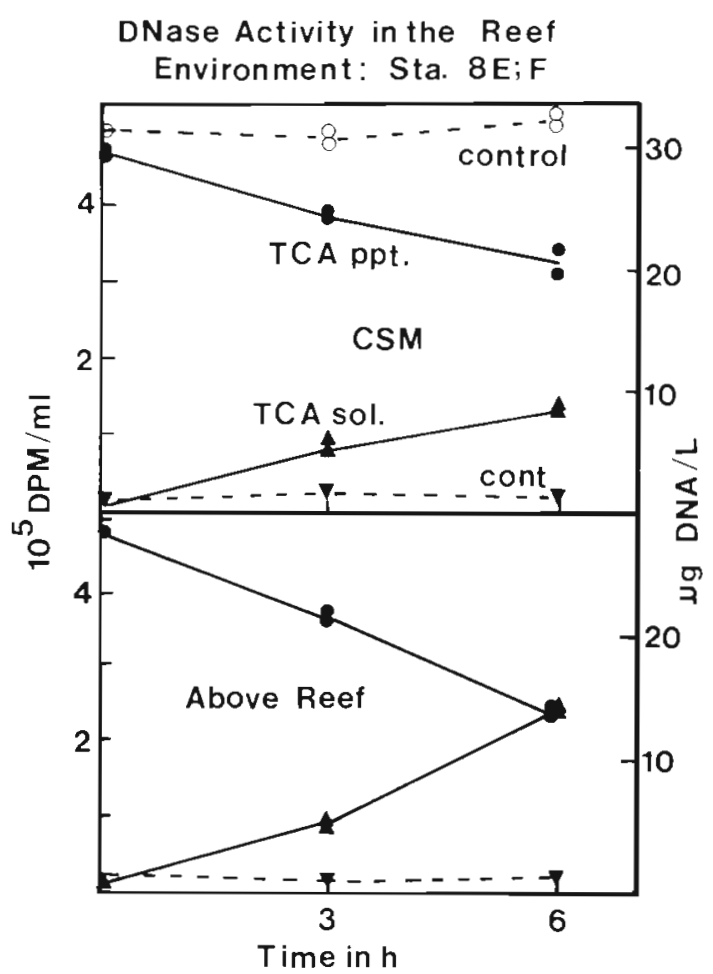

Fig. 7. Extracellular DNase activity in the CSM and overlying water. Water from the CSM and over the reef was sterile filtered through $0.2 \mu \mathrm{m}$ Nuclepore filters and incubated with ${ }^{3} \mathrm{H}$-DNA (details of experiment appear in text). (๑): Disappearance of radioactivity from ${ }^{3} \mathrm{H}-\mathrm{DNA}$ in the TCA-precipitable fraction; ( $\mathbf{\Delta})$ : appearance of TCA-soluble radioactivity; (O): boiled, filtered controls for DNA hydrolysis; ( $\mathbf{\nabla}$ ): appearance of TCA-soluble material

not measured in this study, the CSM is probably rich in regenerated and/or organic forms of nitrogen and phosphorous. The presence of elevated levels of dissolved DNA (a form of both $\mathrm{N}$ and $\mathrm{P}$ ) may be indicative of other biologically labile sources of organic $N$ and $P$ in the coral mucus. Thus, a very efficient cycling of nutrients may be occuring in the CSM, due to the concerted actions of the coral host and bacterial flora.

The presence of extracellular DNase activity in both the CSM and overlying water is also of interest. Maeda \& Taga $(1973,1981)$ also found deoxyribonuclease activity in seawater. Due to the low specific activity of the ${ }^{3} \mathrm{H}$-DNA employed in this study, the substrate concentration ( $\mathrm{Sn}+\mathrm{Sa}$ ) was very much larger than the ambient substrate concentration ( $\mathrm{Sn}$ ), and an ambient rate of hydrolysis cannot be calculated. Although the rates of hydrolysis in the CSM and overlying water appear similar at such a high substrate concentration, ambient levels of dissolved DNA were nearly 4 times greater in the CSM at this site. Despite this, our data clearly demonstrates the capability for DNA (which is abundant in the CSM) to be hydrolyzed by extracellular nucleases. Such extracellular hydrolytic enzymes may participate in the cycling of organic matter and the nutrient regeneration processes in the CSM.

Comparisons of the microbial activity in the CSM and the overlying water on a per volume basis are relative since the CSM samples were inevitably diluted with water in the syringe sampling procedure. Thus, true CSM values per unit volume are probably higher than those we have reported here. Nonetheless, when specific rates of bacterial activity are calculated (thymidine incorporation per cell), the CSM bacteria are clearly growing faster than those in the overlying water. The number of bacteria present in the CSM, although usually greater than the overlying water, was not as great as suggested by thymidine incorporation rates. To maintain these bacterial numbers, some type of bacterial grazing must be invoked (Azam et al. 1983). Since planktonic bacteriovores are scarce in the reef environment (see Ducklow in press) and corals themselves have been shown to feed on bacteria (Sorokin 1973), it seems likely that the corals efficiently maintain a level of bacteria in the CSM through feeding. This might also explain the somewhat lower bacterial density observed in the CSM during the midnight sample, when corals presumably feed more actively. However, this evidence does not preclude the possibility of bactivorous flagellates in the CSM.

Microbial production estimates by ${ }^{3} \mathrm{H}$-thymidine incorporation have come under scrutiny in recent years (Karl 1982). Production estimates based on thymidine incorporation can be hampered by (1) labelling of other macromolecules besides DNA (Moriarty et al. 1985a), (2) isotope dilution by both intracellular and extracellular sources of thymidine (Pollard \& Moriarty 1984) and (3) the lack of thymidine kinase (tdk) in bacteria, particularly pseudomonads (Carlson et al. 1985, Saito et al. 1985). We have found little evidence of non-specific labelling in the reef and offshore environments, but have observed labelling of protein and RNA in estuarine environments (Jeffrey \& Paul 1986). We have not measured isotope dilution in these samples nor have we a method to estimate the fraction of the population capable of utilizing thymidine. Our purpose was to use thymidine incorporation as a relative measure of heterotrophic bacterial activity, in order to compare other environments we have sampled. However, to compare our values to other published values for bacterial activity in the reef environment, it is necessary to estimate production, while acknowledging all the caveats associated with such an endeavor. We have determined the area capable of being sampled with a $50 \mathrm{ml}$ syringe in a uniform motion over a surface, and found that each $\mathrm{cm}^{2}$ of coral surface would result in $5.13 \pm 0.93 \mathrm{ml}$ of CSM volume. We feel this is a conservative estimate, since we have no indication that we have removed all the bacteria in 
Table 5. Bacterial production estimates in the CSM and overlying waters. Bacterial cells produced determined by multiplying moles thymidine incorporated by $4 \times 10^{18}$ (Ducklow \& Hill 1986). To obtain production, a conversion of volume CSM sampled per unit area $\left(51.3 \mathrm{I} \mathrm{m}^{-2}\right)$ was determined experimentally by repeatedly dragging a $50 \mathrm{ml}$ syringe over a submerged surface. Average volume of a CSM cell was determined to be $0.129 \mu \mathrm{m}^{3} \pm 0.124(\mathrm{n}=15)$ and of an overlying water bacterial cell $0.08 \pm 0.05 \mu \mathrm{m}^{3}$ Carbon/unit volume conversion $5.66 \times 10^{-13} \mathrm{~g} \mathrm{\mu m}^{-3}$ (Bratbak 1985)

\begin{tabular}{|c|c|c|c|c|}
\hline Station & $\begin{array}{l}\text { Thymidine inc. } \\
\left(\mathrm{pmol} \mathrm{I}^{-1} \mathrm{~h}^{-1}\right)\end{array}$ & $\begin{array}{l}\text { Bact. cells prod. } \\
\left(10^{6} \text { cells } 1^{-1} h^{-1}\right)\end{array}$ & $\begin{array}{l}\text { Depth } \\
\text { (m) }\end{array}$ & $\begin{array}{l}\text { Production } \\
\left(\mathrm{mg} \mathrm{C}^{-2} \mathrm{~d}^{-1}\right)\end{array}$ \\
\hline \multicolumn{5}{|l|}{ A. $\mathrm{CSM}$} \\
\hline \multicolumn{5}{|c|}{ Loggerhead Key } \\
\hline $8 c$ & 59.8 & 239 & - & 21.3 \\
\hline $8 \mathrm{e}$ & 21.3 & 85.2 & - & 7.7 \\
\hline $8 g$ & 67.9 & 271 & - & 24.4 \\
\hline IVC & 7.84 & 31.4 & - & 2.8 \\
\hline \multicolumn{5}{|l|}{ Garden Key } \\
\hline $9 a$ & 17.6 & 70 & - & 6.3 \\
\hline \multicolumn{5}{|l|}{ Sand Key } \\
\hline $10 a$ & 229.0 & 916 & - & 82.3 \\
\hline \multicolumn{5}{|c|}{ B. Overlying water } \\
\hline \multicolumn{5}{|c|}{ Loggerhead Key } \\
\hline $8 b$ & 0.969 & 3.87 & 2 & 8.4 \\
\hline $8 \mathrm{~d}$ & 0.665 & 2.66 & 4 & 11.6 \\
\hline $8 \mathrm{f}$ & 2.32 & 9.28 & 2 & 20.2 \\
\hline $8 \mathrm{~h}$ & 1.63 & 6.52 & 2 & 14.2 \\
\hline IVd & 2.35 & 9.40 & 2 & 20.4 \\
\hline \multicolumn{5}{|l|}{ Garden Key } \\
\hline $9 b$ & 4.66 & 18.6 & 2 & 40.5 \\
\hline \multicolumn{5}{|l|}{ Sand Key } \\
\hline $10 a$ & 3.36 & 13.4 & 1 & 14.6 \\
\hline
\end{tabular}

the CSM by our sampling. Secondly, we have employed Ducklow \& Hill's (1986) estimate for the number of bacteria produced per mole of thymidine incorporated $\left.\left(4 \times 10^{18} \text { cells [mole thymidine] }\right]^{-t}\right)$ and Bratbak's (1985) value for the carbon per volume of bacteria. Lastly, we have sized bacteria in the mucus and overlying waters by epifluorescence microscopy. The results of these calculations appear in Table 5. The most obvious conclusion from this exercise is that bacterial production in the CSM ( 3 to $82 \mathrm{mg} \mathrm{C} \mathrm{m}^{-2} \mathrm{~d}^{-1}$ ) is on the same order of magnitude as the bacterial production in the entire water column overlying the reef ( 8 to $40 \mathrm{mg} \mathrm{C} \mathrm{m}^{-2} \mathrm{~d}^{-1}$ ). This is surprising in view of the small thickness ( $\mathrm{mm}$ 's) of the CSM. Converting our production estimates back to per unit volume, our values for bacterioplankton production over the reef (2.83 to $19.8 \mu \mathrm{g} \mathrm{C} \mathrm{l}^{-1} \mathrm{~d}^{-1}$ ) are similar to those reported for summer samples by Moriarty et al. (1985a; 25 to 42 $\mu \mathrm{gC}^{-1} \mathrm{~d}^{-1}$ ), by Linley \& Koop (unpubl.; 1.3 to $64 \mu \mathrm{g} \mathrm{C}$ $\left.\mathrm{l}^{-1} \mathrm{~d}^{-1}\right)$, and Sorokin $(1973,1978)$. However our bacterial production values for the water column or the CSM are much lower than those reported by Burns et al. (1984) for the water column (86 to $1985 \mathrm{mg} \mathrm{C} \mathrm{m}^{-2} \mathrm{~d}^{-1}$ ) or the sediment (16 250 to $83000 \mathrm{mg} \mathrm{C} \mathrm{m}^{-2} \mathrm{~d}^{-1}$ ). These workers employed the adenine technique which reportedly measures total community production, which might explain these differences.

Our CSM production values ( 3 to $82 \mathrm{mg} \mathrm{C} \mathrm{m}^{-2} \mathrm{~d}^{-1}$ ) are lower than those reported for salt marsh and coastal zone sediments (100 to $800 \mathrm{mg} \mathrm{C} \mathrm{m}^{-2} \mathrm{~d}^{-1}$; Fallon et al. 1983), but are comparable for sediments of seagrass beds (Moriarty et al. 1985c). The CSM bacterial production values are small when compared to estimates of gross reef production $\left(2\right.$ to $20 \mathrm{~g} \mathrm{C} \mathrm{m}^{-2} \mathrm{~d}^{-1}$, or 0.03 to $4 \%$; Ducklow unpubl.). Our bacterial production values are on the same order of magnitude as primary production in the CSM ( 7 to $75 \%$ of the primary production) and in the water column (9.13 to $119 \%$ ). If Richman et al. 's (1975) estimate of mucus production is reliable (50 $\mathrm{mg} \mathrm{C} \mathrm{m}^{-2} \mathrm{~d}^{-1}$ ), our bacterial production would be comparable to total mucus production (12 to $160 \%$ ). Herndl \& Velimirov (1986) estimated bacterial utilization of coral mucus with a carbon conversion efficiency of $\sim 20 \%$, so that the lower end of these numbers seem reasonable. Yet, it should be emphasized that there are large uncertainties in all of these 
calculations and that similarities between production estimates are due equally to errors in correction factors as to biological principles.

Acknowledgements. We are grateful to Hugh Ducklow for his interest in this project and for providing preprints of submitted work. We are grateful to Walter Bowles and Tracy Logue for help in sampling. This work was supported by NSF grants OCE-8415605, a USF Faculty Research and Creative Scholarship Award, a Florida Institute of Oceanography Shiptime Award, and a Gulf Oceanographic Charitable Trust Foundation Award.

\section{LITERATURE CITED}

Azam, F., Fenchel, T., Field, J. G., Gray, J. S., Meyer-Reil, L. A., Thingstad, F. (1983). The ecological role of water column microbes in the sea. Mar Ecol. Prog. Ser. 10: $257-263$

Benson, A. A., Muscatine, L. (1974). Wax in coral mucus: Energy transfer from corals to reef fishes. Limnol. Oceanogr. 19: 810-814

Bratbak, G. (1985). Bacterial biovolume and biomass estimations. Appl. environ. Microbiol. 49: 1488-1493

Burns, D., Andrews, C., Craven, D., Orett, K., Pierce, B., Karl, D. (1984). Microbial biomass, rates of DNA synthesis and estimated carbon production in Kaneohe Bay, Hawaii. Bull. mar. Sci. $34: 346-357$

Carlson, C. A., Stewart, G. J., Ingraham, J. L. (1985). Thymidine salvage in Pseudomonas stutzeri and Pseudomonas aeruginosa provided by heterologous expression of Eschenichia coli thymidine kinase gene. J. Bacteriol. 163: 291-295

Carpenter, E. J., Lively, J. S. (1980). Review of estimates of algal growth using ${ }^{14} \mathrm{C}$-tracer techniques. In: Falkowski, P. G. (ed.) Primary productivity in the sea. Plenum Press, New York, p. 161-178

DiSalvo, L. H. (1971). Regenerative functions and microbial ecology of coral reefs: Labelled bacteria in a coral reef microcosm. J. exp. mar. Biol. Ecol. 7: 123-136

DeFlaun, M. F., Paul, J. H., Davis, D. (1986). A simplified method for dissolved DNA determination in aquatic environments. Appl. environ. Microbiol. (in press)

Ducklow, H. W. (in press). The biomass, production and fate of bacteria in coral reefs. In: Dubinsky, Z. (ed.) Coral reefs. Springer Verlag, Heidelberg

Ducklow, H. W., Hill, S. M. (1986). Tritiated thymidine incorporation and the growth of heterotrophic bacteria in warm core rings. Limnol. Oceanogr. 30: 260-272

Ducklow, H. W., Mitchell, R. (1979a). Composition of mucus released by coral reef coelenterates. Limnol. Oceanogr. 24: 706-714

Ducklow, H. W., Mitchell, R. (1979b). Bacterial populations and adaptations in the mucus layers on living corals. Limnol. Oceanogr. 24: 715-725

Fallon, R. D., Newell, S. Y., Hopkinson, C. S. (1983). Bacterial production in marine sediments: Will cell specific measures agree with whole system metabolism? Mar. Ecol. Prog. Ser. 11: 119-127

Fuhrman, J. A., Azam, F. (1980). Bacterioplankton secondary production for coastal waters of British Columbia, Antarctica, and California. Appl. environ. Microbiol. 39: $1085-1095$

Fuhrman, J. A., Azam, F. (1982). Thymidine incorporation as a measure of heterotrophic bacterioplankton production in marine surface waters: Evaluation and field results. Mar. Biol. 66: 109-120

Halley, R. B. (1979). Guide to sedimentation for the Dry Tortugas. Southeastern Geological Society, Tallahassee

Herndl, G. J., Velimirov, B. (1986). Microheterotrophic utilization of mucus released by the Mediterranean coral Cladocera cespitosa. Mar Biol. 90: 363-369

Hobbie, J. E., Daley, R. J., Jasper, S. (1977). Use of Nuclepore filters for counting bacteria by epifluorescence microscopy. Appl. environ. Microbiol. 33: 1225-1228

Jeffrey, W H., Paul, J. H. (1986). Activity measurements of planktonic microbial and microfouling communities in a eutrophic estuary. Appl. environ. Microbiol. 51: 157-162

Johannes, R. E. (1967). Ecology of organic aggregates in the vicinity of a coral reef. Limnol. Oceanogr. 13: 189-195

Karl, D. M. (1979). Measurements of microbial activity and growth in the ocean by rates of stable ribonucleic acid synthesis. Appl. environ. Microbiol. 38: 850-860

Karl, D. M. (1982). Selected nucleic acid precursors in studies of aquatic microbial ecology. Appl. environ. Microbiol. 44: 891-902

Karl, D. M., Bossard, P. (1985). Measurement of microbial nucleic acid synthesis and specific growth rate by ${ }^{32} \mathrm{PO}_{4}$ $\left[{ }^{3} \mathrm{H}\right]$ adenine: Field comparison. Appl. environ. Microbiol. 50: 706-709

Kobayashi, Y., Harris, W. G. (1978). LSC applications notes \#1-30. New England Nuclear Corp., Boston

Maeda, M., Taga, N. (1973). Deoxyribonuclease activity in seawater and sediment. Mar. Biol. 20: 58-63

Maeda, M., Taga, N. (1981). Fluctuations of deoxyribonuclease activity from late spring to early autumn in Tokyo Bay. Hydrobiol. 76: 49-55

Maniatis, T., Fritsch, E. F., Sambrook, J. (1982). Molecular cloning: A laboratory manual. Cold Spring Harbor Laboratory, Cold Spring Harbor

Moriarty, D. J. W. (1983). Measurement of muramic acid in marine sediments by high performance liquid chromatography. J. microb. Meth. 1: 111-117

Moriarty, D. J. W., Pollard, P. C., Hunt, W. G. (1985a). Temporal and spatial variation in bacterial production in the water column over a coral reef. Mar. Biol. 85: 285-292

Moriarty, D. J. W., Pollard, P. C., Hunt, W. G., Moriarty, C. M., Wassenberg, T J. (1985b). Productivity of bacteria and microalgae and the effect of grazing by holothurians in sediments on a coral reef flat. Mar Biol. 85: 293-300

Moriarty, D. J. W., Boon, P. I., Hansen, J. A., Hunt, W. G., Poiner, I. R., Pollard, P. C., Skyring, G. W., White, D. C. (1985c). Microbial biomass and productivity in seagrass beds. Geomicrobiol. J. 4: 21-51

Paul, J. H. (1982). Use of Hoechst dyes 33258 and 33342 for enumeration of attached and planktonic bacteria. Appl. environ. Microbiol. 43: 939-944

Paul, J. H., Carlson, D. J. (1984). Genetic material in the marine environment: Implication for bacterial DNA. Limnol. Oceoanogr. 29: 1091-1097

Paul, J. H., Jeffrey, W. H., DeFlaun, M. (1985). Particulate DNA in subtropical oceanic and estuarine planktonic environments. Mar. Biol. 90: 95-101

Paul, J. H., Myers, B. (1982). Fluorometric determination of DNA in aquatic microorganisms by use of Hoechst 33258 . Appl. environ. Microbiol. 43: 1393-1399

Pollard, P. C., Moriarty, D. J. W. (1984). Validity of isotope dilution of tritiated thymidine during incorporation into DNA as an estimate of bacterial growth rates. Appl. environ. Microbiol. 48: 1076-1083

Richman, S., Loya, Y., Slobodkin, L. B. (1975). The rate of mucus production by corals and its assimilation by the 
coral reef copepod Acartia negligens. Limnol. Oceanogr 20: 918-923

Rublee, P. A., Lasker, H. R., Gottfried, M., Roman, M. R. (1980). Production and bacterial colonization of mucus from the soft coral Briarium asbestinum. Bull. mar. Sci. 30: 888-893

Saito, H., Tomioka, H., Ohkido, S. (1985). Further studies of thymidine kinase: distribution pattern of the enzyme in bacteria. J. gen. Microbiol. 131: 3091-3098

Segel, L. A., Ducklow, H. W. (1982). A theoretical investigation into the influence of sublethal stresses on coralbacterial ecosystem dynamics. Bull. mar. Sci. 32: 919-935
Sieburth, J. McN. (1975). Microbial seascapes. Univ. Park Press, Baltumore

Sorokin, Y. I. (1971). On the role of bacteria in the productivity of tropical oceanic waters. Int. Revue ges. Hydrobiol. 56: $1-48$

Sorokin, Y I. (1973). Trophical role of bacteria in the ecosystem of the coral reef. Nature, Lond. 242: 415-417

Sorokin, Y I. (1978). Microbial production in the coral reef community. Arch. Hydrobiol. 83: 281-323

Westrum, B. L., Meyers, P. A. (1978). Organic carbon content of seawater from over three caribbean reefs. Bull, mar. Sci. 28: $153-158$

This article was presented by Dr. S. Y. Newell; it was accepted for printing on July 18, 1986 